\title{
Kætterbegrebet i den danske reformationstid
}

\author{
MARTIN SCHWARZ LAUSTEN
}

\begin{abstract}
ENGLISH ABSTRACT: After the condemnation of Luther for heresy and his own persecution of heretics, the paper describes the judgment of heresy against the layman Melchior Hoffman by the Lutheran authorities in Flensburg (1529). During the spiritual controversy between the Catholic Poul Helgesen (Paul Helie) and the first Danish evangelical preachers both parties accused each other of heresy (1525-1535). In the established Lutheran Church (since 1537) especially Hans Tausen, bishop from 1542, and Peder Palladius, bishop from 1537, would fight what they considered heretics, i.e., Catholics, non-Lutheran Protestants and Jews.
\end{abstract}

DANSK RESUMÉ: I forlængelse af fordømmelsen af Luther for kætteri og hans egen forfølgelse af kættere drøfter artiklen kxtterdommen over lægmanden Melchior Hoffmann ved de lutherske myndigheder i Flensburg i 1529. Som led $i$ den åndelige kontrovers mellem katolikken Poul Helgesen (Paul Helie) og de forste evangeliske forkyndere anklagede begge parter gensidigt hinanden for kætteri (1525-1535). Med den etablerede evangelisk-lutherske kirke fra 1537 gjorde både Hans Tausen, biskop fra 1542, og Peder Palladius, biskop fra 1537, udfald mod, hoad de opfattede som kættere, det vil sige katolikker, ikke-lutherske protestanter og jøder.

Keywords: Luther, Heresy, Poul Helgesen (Paulus Helie), Danish reformation, Hans Tausen, Peder Palladius.

\section{Luther som kætterdømt og kætterjæger}

I løbet af middelalderen udformedes en pavelig lovgivning om indskriden imod filosofiske eller religiøse meninger, som stred mod kirkens lære. Sådanne opfattelser kaldtes kætteri. Det var endvidere en følge af de sociale forhold, at kirkens fjender 
også var det verdslige samfunds fjender. Derfor fulgte den verdslige øvrighed gerne kirkens bandlysning op ved at erklære kættere i "Rigens Acht". Denne ordning gik tilbage til kejser Friedrich II, som ved anvendelsen af dette begreb lod den kirkelige bandlysning efterfølge af den straf, som forbrydere, der havde truet landefreden, idømtes (1220). At "Rigens Acht" blev udtalt over en person betød altså den pågældendes udstødelse af samfundet. Enhver måtte dræbe en sådan person uden at blive straffet for det, og det var kun kejseren, som kunne udtale denne dom.

Helt fra oldkirkens tid havde kirkens ledelse kunnet bandlyse mennesker, som havde gjort sig skyldige i frafald fra den kristne tro, eller begået utugt eller mord. Det blev efterhånden almindeligt, at man anvendte udtrykket ekskommunikation, dvs. uddrivelse af fællesskabet. Det lille band betød udelukkelse fra kirkens sakramenter, en særdeles alvorlig straf i middelalderen, hvor samfundet var religiøst og kirkens sakramente uomgængeligt for at leve et normalt liv. Det store band betød total udelukkelse af det kirkelige fællesskab, og sådan som samfundet var indrettet, betød det også, at den pågældende blev frosset ud af lokalfællesskabet.

I konsekvens af, at Luther havde brændt bandtrusselsbullen i december 1520, udsendte paven selve bandbullen (Decet Romanum Pontificem, den 3.januar 1521 ). Luther blev erklæret kætter. Straffen ville ramme både ham, hans tilhængere og beskyttere. Af politiske grunde, som det ikke er muligt at komme nærmere ind på her, lykkedes det Luthers verdslige øvrighed, kurfyrste Frederik den Vise af Sachsen at få kejser Karl d. 5. til at tillade, at Luther kunne blive forhørt endnu en gang, nemlig på den kommende rigsdag i Worms i foråret 1521. Der blev Luther dømt endeligt. Begrundelsen var hans ulydighed mod paven og hans kætterske meninger om bl.a. afladen og sakramenterne. I kejserens mandat (8. maj 1521) hed det, at det nu var fastslået, at Luther fremførte vranglære og kætteri. Følgerne havde været frafald fra gode sæder, fra freden og fra den kristne tro. Kejseren nævner som eksempler på dette kætteri Luthers afvisning af de syv sakramenter, han håner paven, som forstås som stedfortræder her på jorden for Peter og Kristus selv, han afviser viljens frihed, hævder at messen ikke kommer de kristne til gode, og at det samme gælder faste og bønner. Han foragter de hellige fædres autoritet. Alt dette fører til oprør, splittelser, krig, drab, røverier, brandstiftelser og frafald fra den sande kristne kirke. Det fører til, at mennesker vil føle sig frie over for al lovgivning, han er som Johan Hus, ja Luther er djævelen i menneskeskikkelse, iført en munkekutte. Luther var en forstokket ødelægger af kirken og åbenbar kætter. Kejser Karl d. 5. erklærer pavens kætterdom over Luther for stadfæstet og tilføjer, at han nu erklæres "i Rigens Acht” dvs. at han nu er kætter og fredløs. Ingen må huse ham eller give ham mad, drikke og hjælp. Tværtimod er enhver forpligtet til at fange ham og udlevere ham til straf. Hans skrifter må ikke sælges, købes, læses eller opbevares og udbredes. Uden kirkelig tilladelse må i øvrigt ingen teologiske skrifter trykkes længere (Brecht 1981, 371-453). ${ }^{1}$

1 I det følgende gengives større citater fra Luthers skrifter på dansk. Der henvises i parentes til kildestederne. 
Således havde paven og kejseren samarbejdet om at få Luther udryddet, fordi hans teologi var i modstrid med den katolske kirkes. Som bekendt overlevede Luther - om årsagerne og begivenhedernes forløb må henvises til Lutherlitteraturen - men hvad siger Luther selv til principperne? Hvordan skal man fra kirkens side behandle afvigende meninger? Hans principielle standpunkt er, at kætteri skal bekæmpes med ikke-voldelige midler. Bøn og ord, forkyndelse. I skriftet Eine treue Vermahnung $M$. Luthers zu allen Christen, sich zu hüten vor Aufruhr und Empörung, 1522, opfordrer han til at bede imod paven, ja til at enhver kristens mund ligefrem skal være en mund for Kristi ånd:

\footnotetext{
Vor herre Jesus Kristus vil dræbe ham (paven, Lausten) med sin ånds mund. Det er det, vi gør, når vi trøstigt fortsætter, som vi er begyndt ved hjælp af tale og skrift at afdække det gøgl og bedrag, som paven og papisterne driver blandt folk, indtil det er blotlagt for hele verden og blevet dem til skam. For med ord skal man dræbe dem, Kristi mund skal gøre det, for derved bliver det revet ud af menneskers hjerte, og pavens løgne bliver erkendt og foragtet (WA 8, 682f.).
}

Det viste han selv under Wittenbergurolighederne, hvor han gennem en række prædikener fik drejet folkestemningen og fik de radikale ånder til at forlade byen, og i det kendte "øvrighedsskrift" Von weltlicher Oberkeit, wie weit man ihr Gehorsam schuldig sei, 1523, spørger han, hvem skal bekæmpe kætteri, og svarer:

Det skal biskopperne gøre. Det er dem, ikke fyrsterne, som har fået denne tjeneste pålagt. For kætteri kan man aldrig bekæmpe med magt. Der skal en anden fremgangsmåde til, og her er det en anden kamp end sværdets. Guds ord skal kæmpe her... Kætteri er et åndeligt anliggende, det kan man overhovedet ikke slå ned med våben eller brænde med ild eller drukne med vand. Guds ord er alene om det (WA 11, 268).

Hvem skal da afgøre, om noget er kætteri? Ikke paven, som den katolske kirke ud fra Matt 16 påstår er indehaver af det egentlige kristne læreembede. Det er en falsk fortolkning. Alle former for teologiske meninger og læreopfattelser skal vurderes ud fra Peters bekendelse: “Du er Kristus, den levende Guds søn!" og ikke ud fra pavelig afgørelse. Den kirkelige disciplin skal ganske vist opretholdes med anvendelse af det lille band og det store band, men kirken skal kun anvende det lille band. Offentligt kendte, stædige syndere må ikke få adgang til nadver eller kirkeligt fællesskab. Det store band skal kun anvendes af det verdslige styre for at opretholde ro og orden i samfundet (Vercruysse 1983, 166-8). Et særligt alvorligt problem opstod, da gendøberne begyndte at husere. Man skulle tro, at dette var et åndeligt spørgsmål, men da kejseren indførte dødsstraf imod gendøberne (1530) fik det Luthers tilslutning. Luther gik nu ind for dødsstraf imod dem med den begrundelse at de både hånede den sande kristne tro, og at de var oprørere imod den verdslige øvrighed. Ganske vist skulle man ikke tvinge mennesker til den rette kristne tro, men man var forpligtet til at hindre forhå- 
nelser. I 1531 havde kurfyrste Johann Friedrich bedt sine teologer i Wittenberg om en betænkning om dette spørgsmål. De anbefaler i den dødsstraf mod gendøbernes førere og deres tilhængere Fyrsten er forpligtet til, skriver de, at straffe dem med sværdet. Tilmed afviser teologerne den påstand, at man ikke får noget frugtbart ud af at dræbe dem. Neden under betænkningen har Luther skrevet: "Dette er jeg, Martin Luther, enig i," og han tilføjer, at det kan ganske vist tage sig grusomt ud at dødsdømme dem, men gendøberne selv er endnu grusommere, fordi de fordømmer Ordets tjeneste, undertrykker den sande kristne lære og vil ødelægge det verdslige styre. Teologerne henviser til 3 Mos 24: “den, som håner Gud, skal dræbes!” Desuden nævner de, at de oldkirkelige gendøbere, donatisterne, blev dræbt. Derfor skal både de oprørske gendøbere og de, som teologisk afviger fra den rette lære, dræbes. Men samtidig skal man naturligvis forsøge ad belæringens vej at bringe gendøberne på bedre tanker (Gutachten für Kurfürst Johann von Sachsen, MBW Texte 5, nr. 119, 39-43). Luther blev også engang ved et måltid spurgt, om man må dræbe gendøbere, og han svarede, at de offentligt oprørske gendøbere må en fyrste dømme og dræbe (WATr 5, 20).

\section{Kætterbegrebet i Haderslevreformationen}

I anden halvdel af 1520'erne gennemførte hertug Christian den lutherske reformation i sit lille landområde i det nuværende Sønderjylland med Haderslev som centrum. Uden - så vidt vi kan se - at anvende kætterbegrebet direkte, afsatte hertug Christian nogle præster, som "ikke ville opgive deres papistiske lærdom og afguderi" (Gregersen 1986, 256), ligesom hertugen også i nogle breve søgte at overbevise den katolske biskop i Ribe, Iver Munk, om, at den katolske lære om faste, cølibat, munkevæsen og andet var ubibelsk, løgn, bedrageri og hørte djævelen til. Og da en uluthersk protestant, lægmanden Melchior Hoffmann, turede rundt i det holstenske, blev han kaldt kætter, sværmer og fanatiker og landsforvist efter en såkaldt religionssamtale i Flensborg (1529), hvor hertug Christians teologer, den hidkaldte Johann Bugenhagen og hertugen selv sad i forhørskommissionen og 'diskuterede' med sværmeren (Rørdam 1860-1862, 1-20; Lausten 1963-1965, 237-85).

\section{Kætterbegrebet i den danske reformationskamp}

Karmeliterprovincialen Poul Helgesen blev den mand, som i større omfang påtog sig at forsvare den romersk-katolske kirke over for de fremstormende danske evangeliske prædikanter i 1520'erne og 1530`erne. Det var naturligvis vigtigt for ham at hævde og bevise, at modstanderne var kættere, og i sine skrifter kredsede han meget om kætterbegrebet. Han stillede det spørgsmål, hvor kætteri egentlig kom fra?

Da han havde erfaret, at eksilkongen Christian d. 2. og hans kansler, den tidligere borgmester i Malmø Hans Mikkelsen, i udlandet var gået over til lutherdommen og 
havde udgivet Luthers Nye Testamente på dansk (1524), reagerede han med et ætsende skarpt skrift, Till thet ketterlige wcristelige och wbesindige Breff, som then wbesckemmede Kettere Hans Mickelsen aff Malmø lod wdgaa... (1527). Han håner og hudfletter Hans Mikkelsen personligt, fejer dette danske Nye Testamente bort som et sprogligt makværk og argumenterer kraftigt for, at det er udtryk for en kættersk kristendom. I denne sammenhæng konstaterer han i overensstemmelse med den oldkirkelige teolog Cyprian fra Karthago, at alt kætteri er begyndt med, at lærde mænd har udvist ulydighed mod paver, biskopper og præster. $^{2}$ Det samme gentager han i skriftet Svar til Kong Gøstaff (1528), i hvilket han forklarer den svenske konge, hvorfor lutherdommen er kætteri. Han varierer forklaringen lidt, idet han henviser til kirkefaderen Chrysostomos, som oplyste, at alle kætterier havde deres udspring deri, at kætterne ikke ville finde sig i underdanighed og ikke underordne sig en øvrighed. Enten har de selv stræbt efter magt og indflydelse eller, dersom de ikke kunne opnå dette, bragt uro og forstyrrelse i øvrighedens område, foragtet øvrighedens love og regler, status og værdighed. De har hyklet, at de gik ind for frihed og sandhed, men blot bragt oprør, vildfarelser, ulydighed og mytteri i mange lande (SPH III, 198.281). Et andet karakteristisk træk ved kætterne er, at de plejer at påstå, at Gud har åbenbaret dem ordene, og at de har Bibelen for sig. Sådan har kættere altid påstået, skriver han imod Hans Mikkelsen:

Du råber hele tiden, din kætter, "Guds ord," "Guds ord," ligesom jøderne hos Jeremias råbte "Herrens tempel," "Herrens tempel," "Herrens tempel" (Jer 7,4), men det er da ikke Guds ord, vi strides om, men Guds ords klare og kristelige mening, som du drejer til mord, manddrab, tyranni, røveri, egenvilje, ja til al synd og udyder.

Hans Mikkelsen og de andre lutherske mænd har ikke Helligånden med sig i deres fortolkning, og derfor bliver deres bibelfortolkning kætteri (SPH II, 35.53). Men man skal ikke lade sig bedrage. Kættere i hele kirkens historie har altid prøvet at hævde, at de byggede på Bibelens ord, nogle af dem fremtrådte også som hellige og lærde folk, men det er alt sammen bedrag: "for der kan aldrig findes en sand hellighed i et kættersk samfund, for det er aldeles afskåret fra Kristi åndelige legeme" (kirken, Lausten). Poul Helgesen opremser i denne sammenhæng en stribe af kættere fra oldkirkens tid, men han forklarer også her, at de ikke var kættere, fordi de anvendte Bibelen, men fordi de brugte den forkert og pressede dens indhold ind under en anden mening, end den havde, og som de tidligere hellige folk havde hyldet. De har nemlig lært os at skelne mellem bibelske skrifter og kætteri, mellem den retsindige og den forkerte mening i Skriften (SPH III, 252). Gang på gang fremhæver Poul Helgesen, at kætteri først og fremmest er et spørgsmål om bevidst falsk bibelfortolkning, som han udreder det fx i skriftet Menige Danmarkis Rigis Biscoppers...Geenswar (1533):

2 Citaterne fra Poul Helgesens og fra de evangeliske prædikanters skrifter gengives i det følgende på nudansk. SPH II, 68. 101. 
Det, som man nu strides om i den hellige kirke, drejer sig udelukkende om den sande kristne mening i Den hellige Skrift, om nogle læresætninger, som der nu tvivles og skændes om, selvom de fra arilds tid har været ubestridte og indiskutable blandt alle kristne lærefædre. Alle kætterier, som jo er sekteriske sager, er startet med, at deres mestre og opfindere ikke ville lade sig nøje med den gamle opfattelse, fortolkning og forklaring af Skriften, af troen og af læren. De har derfor skabt sig deres egen mening og opfattelse, og de har stundom været drevet til dette af hovmod, stundom af gerrighed og ofte af andre særlige årsager, som kunne tjene dem til fordel, fremme nye påfund og angreb, enten fordi det skulle tjene dem selv til vellyst og gode eller være til fordel og tjeneste for andre, som de kunne drage en nytte af, som de ellers ikke ville kunne opnå. Sådanne skjulte begunstigelser og egennytte, har skabt mange stridigheder blandt de kristne og forblindet tusinder af mennesker (SPH IV, 116).

Han undlader her heller ikke at udtale sin misbilligelse af, at lægfolk nu er begyndt at beskæftige sig med fortolkning af Bibelen. Han vil ganske vist ikke i almindelighed kritisere, at lægfolk måske kan læse noget i Skriften på deres eget tungemål, som kan føre til Guds ære og deres sjæls salighed, men det forholder sig nu en gang sådan, at "så ofte menigmand er begyndt at fortolke Skriften, har det medført stor uro, fordi de ville behandle det, som de hverken kunne eller havde evner til" (SPH II, 59). Kætteri skyldes nemlig ofte, at man blot har ledt efter sine egne meninger i Bibelen. Det er udtryk for rent og skært hovmod (SPH IV, 115). Kætteri er ofte opstået deraf, at ordene i Skriften er vanskelige at forstå, hedder det med henvisning til kirkefaderen Hieronymus (SPH IV, 179), og det kan lægfolk ikke.

Poul Helgesen tilføjer, at der også er meget, som er befalet og vedtaget i kirken, som ikke står i Den hellige Skrift, og værdien og autoriteten af denne såkaldte tradition understreger han ved at henvise til kirkefædrene Tertullian og Klemens. Dertil kommer, at kætterne ikke regner med alle skrifter i Bibelen. De tager kun det, som tjener deres egne formål, og "digter sig en ny mening" (SPH III, 133-5). En ulykkelig omstændighed ved kætterier er også, at de opildner hinanden og kætterier smitter, de breder sig. Det er en kendt sag, at "kættere priser kættere." Kætteri er ligesom et frugtsommeligt dyr. Inden der er gået et år, har det født 20 eller 30 ligesindede (SPH IV, 307; III, 35). Hvad skal man da stille op med kættere? Der er en vis mulighed for, at de opgiver deres falske lære og omvender sig, og derfor skal man også bede for dem (SPH III, 189). Men man skal navnlig prøve at overbevise dem om, at de tager fejl, og her har kirkens ledelse, paven, altid været på vagt og skredet ind, når det var nødvendigt. Poul Helgesen fremfører her igen den afgørende katolske lære, at grundlaget for kirkens sande lære er både Bibelen og traditionen, dvs. samlingen af paveudtalelser, helgenberetninger, vedtagelser. En "mådelig" afvisning ville være det bedste, men "da vi nu trænges og tvinges af kristenhedens åbenbare fjender, da må og skal vi også tilkendegive, at vi mangler hverken hænder eller tænder, når det vil være nødvendigt til vor Guds hæder og ære" (SPH II, 239). 
Denne trussel gentager han også, idet han citerer Bernhard af Clairvauxs ligefremme ord om, at kættere er uimodtagelige for gode argumenter, for kirkefædrenes ord, for de er bortvendte fra Gud, ja de vil hellere dø end omvende sig til den sande lære. Derfor ender det for deres vedkommende med fordømmelse og helvedes ild. Dersom de, trods kristne menneskers bøn til Gud, ikke vil omvende sig, men forhærder sig i deres ondskab, "da bliver deres løn det, som står sidst i Fadervor (Fri os fra det onde, Lausten) det betyder: Alt ondt, Amen" (SPH IV, 322), altså udryddelse.

Disse generelle bestemmelser af hvad kætteri er, hvorfra det kommer, hvad kætternes bevæggrunde er, anvender Poul Helgesen så på Luther og de danske lutherske prædikanter. "Mon det var en løgn, at Morten Luther og alle hans tilhængere i lærdom, sind og mening rettelig blev bandlyst?," spørger han prædikanterne (SPH IV, 311; II, 4). Han opregner de dele af Luthers teologi, som er rent kætteri, hævder, at det er en gentagelse af tidligere kætterier og kan konkludere, at den lutherske teologi er "et pestbefængt kætteri" (Skibykrøniken, 151). I sine mange skrifter imod de danske prædikanter søger han også at vise, at deres teologi er det rene kætteri, løgn og skurkestreger, som vildleder lægfolket. Hans Mikkelsen er kætter, rigshofmester Mogens Gøye er den mest kætterske af alle kættere, Hans Tausen er den mest halsstarrige af alle kættere (111, ibid. 140). Alle mennesker skal afsky disse Lutheruler (et hånende ord, som $\mathrm{PH}$ vist selv har skabt), for de er bandsmennesker, indtil de har vendt sig bort fra deres patron, djævelen (SPH IV, 321). Da evangeliske prædikanter i Viborg havde sagt, at ulærde hårdnakkede messepræster forhånede den evangeliske lære og ledte arme mennesker på afveje, hævdede Poul Helgesen, at prædikanterne overhovedet ikke kunne udtale en kætterdom, for de faldt selv ind under den kætterdom, som var udtalt over Luther i Worms 1521, de evangeliske er ikke kristne, men kættere. Den evangeliske menighed i Viborg er ikke Guds kirke, men "Satans forsamling og en forbandet kirke" (SPH IV, 310-20).

Kætterianklagen, udtalt af en biskop og af Poul Helgesen i trykte skrifter var naturligvis alvorlig, og den trussel, som Poul Helgesen citerer fra Bernhard af Claivaux, er ikke til at tage fejl af. De steder, hvor den katolske kirke endnu havde enevældig magt og støttedes af den verdslige øvrighed, som tilfældet var fx i Nederlandene, blussede kætterbålene livligt netop på denne tid. I Danmark har man formentlig også vidst, at ekskonge Christian d. 2.'s hoffourer Wilhelm von Zwolle var blevet brændt levende på torvet i Mecheln (29. oktober 1529), fordi inkvisitionen havde erklæret ham for notorisk kætter. Trods mange forsøg ville den fængslede Wilhelm ikke opgive sin lutherske tro. En bog om de spørgsmål, inkvisitionen stillede ham, hans svar og bekendelser, udkom i Wittenberg året efter (Lausten 1995, 195-211). I Danmark havde den katolske kirke dog næppe mulighed for at gennemføre kætterprocesser. De katolske indledte ikke en kætterproces imod prædikanterne, men ingen kunne naturligvis vide, hvordan fremtiden ville forme sig. Dog kan det tage sig ud, som om ordene kætteri, kætter og kætterisk, som Poul Helgesen slyngede om sig med i skrift efter skrift var reduceret til floskler, ganske vist alvorlige nok, men åbenbart ikke så alvorligt ment, at man skulle indlede retlige skridt imod prædikanterne. 
Ganske som Poul Helgesen ustandseligt omtaler de evangeliske modstandere som kættere, er det tilfældet i skriftet Krøniken om Gråbrødrenes fordrivelse fra deres klostre $i$ Danmark (ca. 1532/37). Foruden Poul Helgesens forfatterskab er dette en af de få samtidige større beretninger fra katolsk side. En barsk beretning om den behandling, som franciskanerklostrene i de danske købstæder blev udsat for af evangeliske prædikanter og andre folk. Navnlig anklager forfatteren rigshofmester Mogens Gøye, men også Frederik d. 1. og andre navngivne. Rigshofmesteren kaldes "på én gang både kætternes beskytter og selv meget kættersk" (Heilesen 1967, 54), og det er karakteristisk, at de evangeliske mænd hele bogen igennem kaldes kætterne. Bogen indledes med En bøn mod kætternes og djævelens rænker og fristelser, i hvilken Gud anråbes om at sende hjælp til den danske franciskanerorden, som nu "er blevet bedraget af kættere og falske prædikanter og antændt af ild og undergravet," og forfatteren beder Gud om, at "kætterne selv må omkomme ved dit åsyns trussel" (Heilesen 1967, 23-6).

Hvad sagde prædikanterne til at blive anklaget for kætteri? Det afviste de naturligvis heftigt. Odensebiskoppen Jens Andersen Beldenak havde sendt et advarende brev til indbyggerne i Viborg og Ålborg (1527), nævnt Luthers kætteri og hævdet, at Luther var skyld i krige, uro, mord, brand, bondeoptøjer osv. i Tyskland, og at alt dette også ville følge i Danmark, hvis de troede på det kætteri. Det gav Hans Tausen anledning til et længere modskrift, hvor han skarpsindigt og polemisk afviste anklagerne mod Luther, hvis teologi og fortolkningskunst han roste og tilsluttede sig. I dette skrift - Edt kort antswor till bispenss sendhæbreff aff Othense (1529) - kom han flere steder ind på begrebet kætteri. Interessant nok definerer han kætteri på samme måde som sin fjende Poul Helgesen: kætteri skyldes, at nogle har fortolket Bibelen på en falsk måde. I denne sammenhæng nævner han nogle af de kendteste kættere i oldkirken og omtaler kortfattet deres kætteri, Arius, Sabellius, Mani og Photinus: "disse og flere andre kættere agtede at bevise det hele ud fra Skriften og Kristi ord." Også nyere teologer som Thomas af Aquinas, Duns Scotus, Bonaventura og Nicolaus de Lyra var uenige om meget, og sådan går det, når sådanne mænd bliver formørket $\mathrm{i}$ deres forstand og evne til at vurdere rigtigt. De har tillagt Bibelen talrige meninger, og derfor er der nogle, som ligefrem kalder Bibelen for "en ret kætterbog". Det skyldes ikke Bibelen selv, men den misbrug, som man har brugt den til (Tausen 1529, 54f.).

En mand, som i det ydre fremtræder som en rigtig katolsk præst, men bare lader munden løbe med latinske bønner, som han ikke selv forstår, bliver af den katolske kirke anset for at være "en dannemand oc en god prestmand," hedder det i prædikanten Peder Laurenssens Malmøbog (1530), og hvis en af disse præster, får den nåde af Gud at kunne skelne mellem falsk og sandt, mellem Guds ord og menneskers digteri og påfund, så fordømmes han straks som kætter og foragter (fol.12b). Det, som er sand kristendom, kalder de katolske kætteri, undervisning i den sande form for kristendom kalder de kætteri (Laurenssen 1530, fol.12b. 56-56b). I den redegørelse for deres tro, som prædikanterne præsenterede i København ved det møde, som skulle være en endelig diskussion om protestantisme og katolicisme (1530) anklager de den katolske kirkes ledere for, at de råber "kætter" efter dem, som forkynder sandheden rigtigt, og 
i deres sammenfatning vil de over for konge, rigsråd, ja hele verden erklære, at de "er kristne mænd og ikke kættere, som de sande kættere, Guds ords og sandheds modstandere påstår om os uden nogen rimelighed eller ret bevis" (The artickle Scrifft oc handell.., 10).

Det er tværtimod den katolske modpart som er kætter. "Kættere er nemlig," siger Malmøprædikanten Peder Laurenssen, "de, som fremfører noget imod troen og leder folket på afveje og forkynder og indfører andet til retfærdighed og salighed end Guds ord og evangeliets hellige lære rent og klart" (Laurenssen 1533, 62). Derfor er netop de katolske modstandere kættere. De kender simpelthen ikke den sande kristendom, skriver prædikanterne i det ovennævnte bekendelsesskrift, og derfor ved de heller ikke, hvad kætteri er efter Bibelens og den gamle kirkes mening. De siger om os, at vi er "kættere og bandskroppe," men det er de overhovedet ikke kvalificerede til at udtale sig om! (The artickle oc handel..., 9). Således bandlyste begge parter hinanden og råbte "kætter" efter hinanden, og de anvendte de samme skriftsteder fra Det nye Testamente som begrundelse, men den katolske part kunne også henvise til det, som for dem var øverste autoritet, pavens dom over Luther og hans tilhængere - en autoritet, som prædikanterne netop ikke ville anerkende. På denne baggrund skulle man tro, at den katolske kirke havde anlagt i stribevis af kættersager imod de lutherske prædikanter. Var det tilfældet? Bortset fra sagen mod Hans Tausen kender vi ikke en eneste. En af årsagerne var, at kong Frederik d. 1. allerede i 1526 var begyndt at udstede de såkaldte værnebreve til fremtrædende lutherske prædikanter, naturligvis stik imod den håndfæstning, som han havde svoret at ville overholde. De katolske prælaters indsigelse mod dette, tog han sig ikke af, og efter herredagen i Odense i 1527 var biskoppernes mulighed for indskriden med kætterproces imod de evangeliske prædikanter helt faldet bort. Frederik d. 1. afviste blankt, at biskopperne skulle have jurisdiktion over præster og munke, som havde forladt den katolske kirke. Troen var nemlig en fri sag, erklærede kongen, og man kunne ikke tvinge nogen til en bestemt tro, ligesom man heller ikke måtte tvinge nogen fra en bestemt tro. Det betyder dog ikke, at der ikke var tilfælde, hvor kirken i 1520’erne på anden vis reagerede imod de evangeliske prædikanter, fordi den hævdede, at de var kættere.

Da biskop Ove Bille, Aarhus, således havde erfaret, at en præst ved navn Simon [Skaaning], var begyndt at forkynde lutherdom i en by i stiftet (Randers?), henvendte han sig (1526), karakteristisk nok, til byens verdslige øvrighed og oplyste, at han havde erfaret, at Simon prædikede lutherske og kætterske artikler imod den kristne lære og orden, som ellers havde hersket i århundreder. Han opfordrede byen til at straffe Simon og eventuelle tilhængere, og han truede byen med ulykker i modsat fald. Vi kender i øvrigt ikke noget nærmere til denne sag. ${ }^{3}$ Under den proces, som biskopperne anlagde mod Hans Tausen, da de efter kong Frederik d. 1.'s død i foråret 1533 en kort overgang sad med magten, blev han dømt at være "kætter, løgner, tyv og skalk," hjemfalden til 
dødsstraf. Men dommen formildnedes til et prædiken- og skriveforbud og til landsforvisning fra Sjællands og Lunds stifter (Lausten 2011, 106-8).

\section{Reformationskirken og kættere efter 1536}

Hele reformationskampen og Christian d. 3.s gennemførelse af den lutherske reformation skal ikke behandles her. Med ét var forholdet vendt om. De katolske kætterjægere sad nu selv på anklagebænken. Hvad stillede de nye magthavere, den lutherske regering og kirke, da op med kætterbegrebet? Ved reformationens gennemførelse fulgte man i et vist omfang Luthers princip om at adskille det åndelige og det verdslige. Men det var ikke så enkelt, at de nye lutherske biskopper eller præster helt mistede muligheden for at straffe mennesker. Den danske kirke havde - ganske vist under en vis modstand fra rigsrådet - bevaret de gejstliges ret til at bandlyse folk. Dette middel kunne tages i brug, hed det i den lov, som indeholdt bestemmelser om den oprettede lutherske kirke (Kirkeordinansen), over for horkarle, skørlevere. Der tilføjes et etc. Dette betød vel, at den gruppe af mennesker, som nævntes som udelukkede fra nadveren, også hørte hjemme blandt dem, nemlig ågerkarle, svirebrødre, urostiftere, voldsmænd, Guds ords foragtere, alle de, som begår syndige handlinger offentligt, selvom de kalder sig evangeliske. Andre som forbydes adgangen til nadveren, er "de, som forhærdet holder fast ved et åbenbart kætteri" samt afsindige mennesker og børn. Bandlysningen skulle først og fremmest anvendes som et middel i nadvertugten. De bandlyste måtte dog gerne komme i kirken og høre prædiken. Men det er tydeligt nok, at lovgiveren ville prøve at undgå, at bandlysningen skulle minde om den katolske kirkes straffeform. Man måtte gerne have "en menneskelig omgang" med dem, men på den anden side måtte man ikke behandle en sådan bandlyst som "en broder." Det må unægtelig have været svært at praktisere både i købstæderne og i de små lokalsamfund (Kirkeordinansen 1537/1539, 184-6). Men det fremhæves derefter direkte i loven, at alle andre forhold hører ind under den verdslige øvrighed. Hvad er det for forhold? Det er "Gudsbespottere, horkarle, jomfrukrænkere, kirkerøvere, de, som ugudeligt overfalder kirker." Sådanne mennesker hører nemlig også ind under "sværdet", og "sværdet" er forpligtet til så meget som muligt at tjene kirken. Loven foreskrev også, at biskoppen ved ordinationen af en præst bl.a. skulle indskærpe ham pligten til "med den sande lære at modstå enhver vildfarelse," og det samme indskærpedes naturligvis også ved indsættelse af biskopper (Kirkeordinansen 1537/1539, 194).

I kongebrevet, som indleder Kirkeordinansen, oplyses om baggrunden for den gennemførte reformation af kirken, faserne i selve lovens udarbejdelse, om det teologiske indhold i den lære, som den dansk-norske kirke nu er funderet på, og navnlig foretages der et særdeles polemisk opgør med den katolske tro og kirkelige praksis. Ordet kætteri optræder ikke, men ingen lades i tvivl om, at det er en fuldstændig forfalsket form for kristendom, og de, som hidtil har været den hellige kirkes hoveder - de katolske biskopper - skal dømmes af Kristus, fordi de blot var optaget af at gavne sig 
selv, hedder det truende. Den katolske kirke fremførte simpelthen "djævelens lære" og hyklede, at det var sand gudstjeneste, men hele denne "antikristelige lære, denne løgn og dette bedrageri sender vi nu hjem til djævelen, hvor det hele kom fra." En hårdere dom kan ikke fældes over et kristent samfund. I slutningen af kongebrevet trues undersåtterne med kongens straf, dersom de ikke retter sig efter kirkeordinansen, dvs. at den katolske tro er blevet forbudt og den evangeliske påbudt. Kirkens ledende mænd skulle nu forestå omskolingsprocessen (Ibid., 150-6).

I sin Postille (1536) kommer Hans Tausen ofte ind på kætterbegrebet og retter voldsomme anklager mod "fordærvelige sekter under det kristelige navn." Hvis der tilmed er tale om et egensindigt kætteri, skal man prøve at belære den pågældende med det gode, og hjælper dette ikke, skal man bandlyse ham og tage afstand fra ham og i øvrigt bede for ham og prøve at påvirke ham gennem et godt eksempel. Man må altså ikke indtage det standpunkt, "at den ugudelige skal miste sit liv på grund af sin vantro og ugudelighed." Kristne fyrster må ikke tvinge nogen til troen, og de, som har gjort det har lært det af paven og hans folk, som rask væk har brugt "fængsel og ild" imod dem, uanset at de har ret. Således afviser Hans Tausen den katolske kirkes fremfærd med kætterprocesser, tvangsmidler og dødsstraffe. Men Gud har bestemt, at vi blot skal lade en ugudelig leve, for på dommens dag vil han blive straffet af ham:

Derfor skal vi lade ham undgå verdslig straf, vi skal ikke straffe nogen på livet på grund af hans falske og kætterske tro og lære, hvis han ellers opfører sig ordentlig over for folk og ikke forbryder sig mod den verdslige fred og ikke stjæler, myrder, horer eller opfordrer til det. På dommedag vil Kristus nemlig kaste sådanne tidsler, torne og ukrudt, som for nu fører sig frem med stor hellighed, "udi den hede helvedes glød" (Tausen 1539, I, CXXIIII - CXXIX).

Sjællands første lutherske biskop Peder Palladius forklarede også flere steder, hvorfor den katolske tro var kætteri. I sin En nøttelig Bog om S. Peders Skib / det er / om den Hellige oc Christelige Kircke (1554) tager han udgangspunkt i billedet af kirken som et skib, der sejler op gennem historien. Gang på gang er det lige ved at synke, fordi der slæbes så meget tyngende, forkert gods ombord, men i sidste øjeblik udrenses der, skibet reddes og kan sejle videre. I bogen foretager Palladius først en kronologisk gennemgang af hovedfaserne i den kristne kirkes historie, og derefter beskriver han kortfattet de vigtigste kristne dogmer. Hovedformålet med hele bogen er at påvise, at den katolske kirke er en ren kættersk forsamling med paven i spidsen som den antikristne hovedkætter. I de mange 'prædikener' bevæger han sig op gennem hele kirkehistorien og søger gang på gang at bevise, at katolicismen er et rent kætteri, "idel skalkhed og bedrageri," og gang på gang hævder han, at det er djævelen selv, som ved hjælp af paver og andre har indført dette. Hvad er nemlig kætteri? spørger han og svarer:

$\mathrm{Nu}$ er og kaldes den en kætter, som eftertrykkeligt fremfører sin egen mening imod den hellige skrifts rette mening. Han har vredet sin egen mening ud af den, og han har gjort 
det af ond hensigt, af ærgerrighed og af en falsk dømmekraft og forstand, eller af had og stolthed og ugudelighed og modstand (Palladius 1554, 91).

I praksis fulgte Palladius dette op i sine Visitatsrunder i det store sjællandske stift, hvor han tydeliggjorde, at al papisme og munkelærdom var afguderi og falsk gudsdyrkelse. Men han beskæftigede sig også flittigt i teologiske forelæsninger og bøger med kætteriet. I 1557 udkom i Wittenberg hans Catalogus aliqvot haeresium huius aetatis et earum confutatio. Palladius vil følge, skriver han, Augustin, som i sin tid gjorde op med talrige kætterier. Derfor vil Palladius de kætterier til livs, som er opstået under pavedømmet og i Palladius' egen tid. Først nævner han det pågældende kætteris hovedindhold, hvorefter han pædagogisk, opstillet i flere punkter, gendriver det. Et andet kætterskrift af Peder Palladius er hans Catalogus Hereticorum secundum ordinem alphabeticum, dateret 1556, skrevet af Morten Pedersen fra Grenå. Det er først i nyere tid blevet udgivet efter et håndskrift i et samlingsbind fra 1558 i Västerås Stifts- och landsbiblioteket, Sverige. Det latinske skrift på 65 sider er i store træk en gengivelse af Augustins De Hæresibus, suppleret med store selvstændige afsnit af Palladius og opstillet på en anden måde end Augustins. I disse afsnit gendriver Palladius navnlig den romersk-katolske tro, jødedommen og gendøberne. Det latinske sprog, gloser på hebraisk og græsk viser, at skriftet ikke var beregnet for lægfolk, men har formentlig været et forelæsningsmanuskript.

\section{BIBLIOGRAFI}

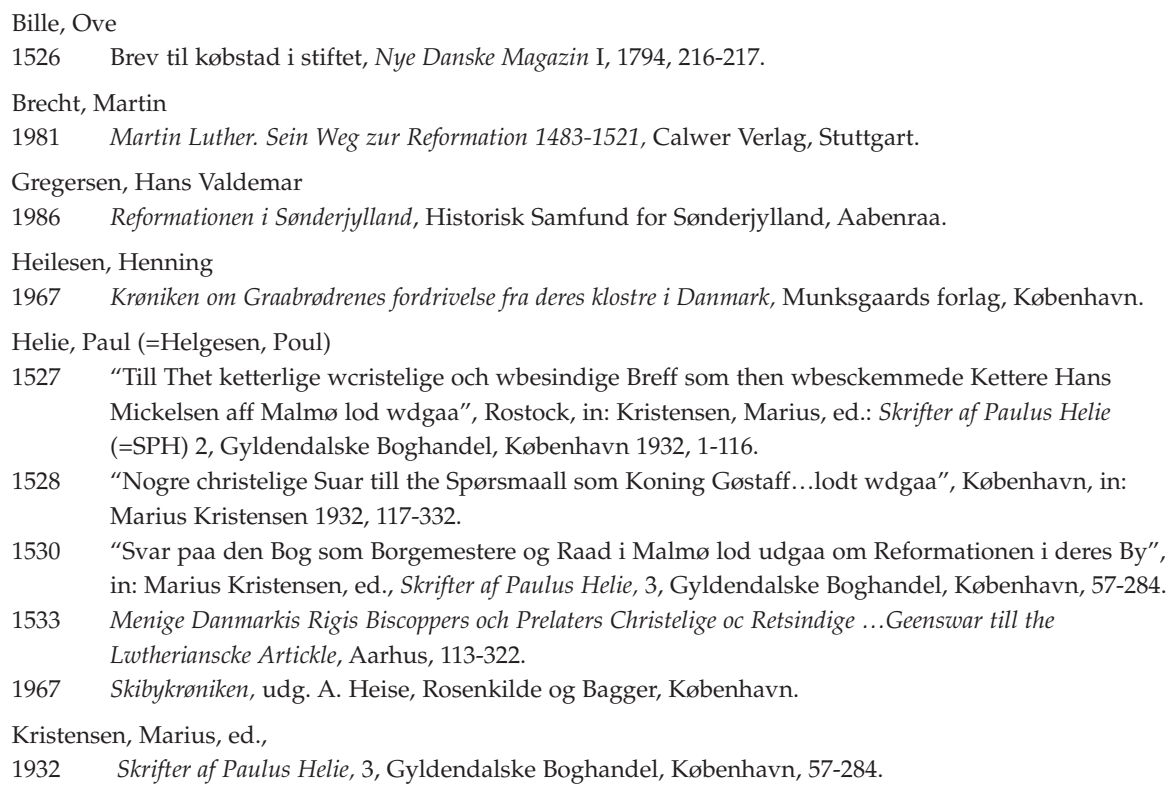


Laurenssen, Peder

1530 Orsagen oc een rett forclaring paa then ny Reformats...som begyndt och giort er vdi then christelige Stadt Malmøe, Malmø 1530.

1533 "En stacket vnderuisning aff Guds egne ord", in: H.F. Rørdam, ed., Skrifter fra Reformationstiden, 5 , 1885-1890, Thieles Bogtrykkeri, København.

Lausten, Martin Schwarz

1963-1965 Melchior Hoffman og de lutherske prædikanter i Slesvig-Holsten 1527-1529, Kirkehistoriske Samlinger 7. Række, V, 1963-1965, 237-285.

1995 Christian d. 2. mellem paven og Luther. Tro og politik omkring "den røde konge" i eksilet og i fangenskabet (1523-1559), Akademisk forlag, København.

2011 Reformationen i Danmark, 3. udgave, forlaget Anis, København.

Lausten, Martin Schwarz, ed.

1989 Kirkeordinansen 1537/39, tekstudgave med indledning og noter, Akademisk forlag, København.

Luther, Martin

1883f. Kritische Gesamtausgabe, Bd. 1-57 (=WA). Tischreden (=WATr), Weimar.

Melanchthon, Philipp

1531 Gutachten für Kurfürst Johann, in: Heinz Scheible, ed., Melanchthons Briefwechsel. Texte, 5, nr. 119, fromann-holzboog Verlag, Stuttgart-Bad Cannstatt 2003, 39-43 (=MBW)

Palladius, Peder

1554 "Sankt Peders Skib", in: Lis Jacobsen, ed., Peder Palladius' Danske Skrifter, 3, 1916-1918, Thieles Bogtrykkeri, København.

1556 "Catalogus Hereticorum secundum ordinem alphabeticum", in: Martin Schwarz Lausten, Catalogus Hereticorum. Et hidtil utrykt skrift af Peder Palladius, Kirkehistoriske Samlinger 1970, 12-45.

1557 Catalogus aliqvot haeresium huius aetatis et earum confutatio, Wittenberg.

Rørdam, Holger Frederik

1860-1862 En theologisk Brevvexel mellem hertug Christian i Haderslev og Biskop Iver Munk, Kirkehistoriske Samlinger 2. Række, II, 1860-1862, 1-20.

Tausen, Hans

1529 Edt kort antswor till bispenss sendhæbreff aff Othense, huilcketh hand tilskreeff the borgheræ $i$ Wiborg och Olborg, in: Fem Reformationsskrifter trykt af Hans Vingaard $i$ Viborg 1528-1530, udg. UniversitetsJubilæets danske Samfund, C.A. Reitzels forlag, København 1987, 25-80.

1539 "Postil I-II", in: Bjørn Kornerup, ed., Hans Tausens Postil, Facsimileudgave, Levin og Munksgaards Forlag, København 1934.

NN

1530 "The artickle Scrifft oc handell, som vore mellom werdige fædre Danmarckss Prelater oc Ewangeliske predickere heer aff riiget nu siste herredag i Køpnehaffn", Malmø, in: Holger Frederik Rørdam, ed., Skrifter fra Reformationstiden, 4, Thieles Bogtrykkeri, København 1885-1890.

Vercruysse, Jos

1983 "Schlüsselgewalt und Beichte bei Luther", in: Helmar Junghans, ed., Leben und Werk Martin Luthers von 1526 bis 1546, I, 153-169. II, 775-781, Leipzig.

Martin Schwarz Lausten, professor emer., dr.theol. Teologisk Fakultet, Københavns Universitet 